\title{
HUBUNGAN PROMOSI PENGGUNAAN KONDOM, SEKS AMAN TERHADAP PENCEGAHAN PENYAKIT MENULAR SEKSUAL DI PUSKESMAS KUTA ALAM BANDA ACEH
}

\author{
Agustina $^{1}$, Munadi ${ }^{2}$ \\ ${ }^{1}$ Bagian Kesehatan Reproduksi Fakultas Kesehatan Masyarakat, Universitas Muhammadiyah Aceh \\ ${ }^{2}$ Bagian Patologi klinik Fakultas Kedokteran Unsyiah

\begin{abstract}
THE RELATIONSHIP OF THE PROMOTION THE USE OF CONDOMS, SAFE SEX AGAINTS A SEXUALLY TRANSMITTED DISEASE PREVENTION AT THE PUBLIC HEALTH CENTER OF KUTA ALAM BANDA ACEH
\end{abstract}

\begin{abstract}
Background: Sexually Transmitted Infections often called Venereal disease it is a disease that is mostly transmitted through sexual intercourse or sexual contact. Since it was first discovered (1987) until June 2012, cases of HIV / AIDS spread in 498 districts / cities throughout the (33) provinces in Indonesia, in 2010 about 21.591 cases in 2011 as many as 21 .031 cases, for Aceh alone there were 65 cases of HIV. The purpose of the study to determine the relationship of promotion of condom and safe sex with the prevention and reproduction of STDs in woman of childbearing age.

Method: The sample in this study were all woman of fertile age (WUS) at risk aged 21-35 years came to Klinik IMS Health Center Kuta Alam Banda Aceh amounted to 63 people. The sampling technique in this research is Consecutive sampling analysis of univariate and bivariate data.

Results: The results of the statistical test Chi-square Condom promotion obtained value of $p=0.013$ and Safer Sex, $p=0.029$ means there is a significant relationship between the Promotion of Use Condoms, Safe sex with the prevention of sexually transmitted infections.

Conclusion: STI prevention and through promotion of safe use of condom and sex at Kuta Alam Health Center is still not good. It is expected that health workers will be more active in implementing the Information, Communication, Education so that it can provide an understanding that can increase public awareness in doing STI prevention and control.
\end{abstract}

Keywords: Condoms, safe sex, STIs

\begin{abstract}
ABSTRAK
Latar Belakang: Infeksi Menular Seksual sering juga disebut Penyakit kelamin ini merupakan penyakit yang sebagian besar ditularkan melalui hubungan seks atau hubungan kelamin. Sejak pertama kali ditemukan (1987) sampai dengan Juni 2012, kasus HIV/AIDS tersebar pada 498 kabupaten/kota di seluruh (33) provinsi di Indonesia, tahun 2010 sebanyak 21.591 kasus, tahun 2011 sebanyak 21.031 kasus, untuk Aceh sendiri terdapat 65 kasus HIV. Tujuan Penelitian untuk mengetahui hubungan promosi penggunaan kondom dan seks aman dengan pencegahan dan penanggulangan PMS pada Wanita Usia Subur.

Metoda: Sampel dalam penelitian ini adalah seluruh Wanita Usia Subur (WUS) beresiko yang berusia 2135 tahun yang datang ke Klinik IMS di Puskesmas Kuta Alam Banda Aceh berjumlah 63 orang. Teknik sampling dalam penelitian ini adalah Consecutive sampling Analisis data secara univariat dan bivariat.

Hasil: Hasil uji statistik Chi-square Promosi kondom didapat nilai $p=0,013$ dan Seks Aman, nilai $p=0,029$ artinya ada hubungan yang signifikan antara Promosi Penggunaan Kondom, seks Aman dengan Pencegahan Infeksi Menular Seksual.

Kesimpulan: Pencegahan dan penanggulangan IMS melalui promosi penggunaan kondom dan seks aman di Puskesmas Kuta Alam Banda Aceh masih kurang baik. Diharapkan petugas kesehatan agar lebih aktif melaksanakan Komunikasi, Informasi, Edukasi sehingga dapat memberikan pemahaman yang dapat meningkatkan kesadaran masyarakat dalam melakukan pencegahan dan penanggulangan IMS.
\end{abstract}

Kata Kunci: Kondom, seks aman, penyakit menular seksual

Alamat Koresponding: Agustina, Jl. Muhammadiyah No.93 Gedung Fakultas Kesehatan Masyarakat Universitas Muhammadiyah Aceh, Batoh-Lung Bata Banda Aceh, Indonesia 23245 Email: agustina.260880@gmail.com 


\section{PENDAHULUAN}

Infeksi Menular Seksual sering juga disebut penyakit kelamin merupakan penyakit yang sebagian besar ditularkan melalui hubungan seks atau hubungan kelamin. Sebelum dikenal sebagai IMS, jenis penyakit ini sudah cukup lama dikenal dengan sebutan penyakit kelamin (venereal disease) yang berasal dari kata venus (dewi Cinta). Saat ini penyakit kelamin yang dikenal baru sifilis (syphilis) dan gonore (gonorrhea), sedangkan istilah IMS baru dikenal setelah ditemukannya jenis penyakit kelamin selain kedua jenis di atas. IMS dikenal pula dengan sebutan Penyakit Akibat Hubungan Seksual (PHS) atau Sexually Transmitted Disease (STD). ${ }^{1}$

IMS dan HIV/AIDS dapat timbul pada semua orang yang berhubungan kelamin dengan banyak pasangan atau bahkan dengan satu pasangan yang telah berhubungan seksual dengan orang lain. Di Indonesia, dari bulan Oktober sampai dengan Desember 2012 jumlah infeksi baru HIV yang dilaporkan sebanyak 6.139 kasus. Dimana persentase infeksi HIV tertinggi dilaporkan pada kelompok umur 25-49 tahun $(61,6 \%)$, diikuti kelompok umur diatas 50 tahun $(20,1 \%)$ dan kelompok umur 20-24 tahun $(12,5 \%)^{2}$

Meningkatnya angka kejadian penyakit Infeksi Menular seksual dikalangan dewasa muda terutama wanita merupakan bukti bahwa wanita dalam hal ini sering menjadi korban dari IMS. ${ }^{3}$ Pada dasarnya setiap orang yang sudah aktif secara seksual dapat tertular IMS. Namun yang harus diwaspadai adalah kelompok beresiko tinggi terkena IMS yaitu orang yang suka berganti-ganti pasangan seksual. Orang yang mengidap IMS memiliki resiko yang lebih besar untuk terinfeksi HIV yang ditularkan melalui hubungan seks. Penderita IMS mempunyai resiko 2-9 kali lebih besar untuk tertular HIV dibandingkan bukan penderita. ${ }^{4}$

Data Kasus Penyakit Menular Seksual di Aceh

\begin{tabular}{lll}
\hline Kasus Penyakit IMS & Tahun $\mathbf{2 0 1 1}$ & Tahun 2012 \\
\hline Sifilis & 15 orang $(16,13 \%)$ & 62 orang $(22,96 \%)$ \\
Gonore & 48 Orang $(51,61 \%)$ & 36 orang $(13,3 \%)$ \\
Uretritis & 2 Orang $(2,15 \%)$ & 5 orang $(1,85 \%)$ \\
Servicitis & 2 orang $(2,15 \%)$ & 44 orang $(16,29 \%)$ \\
Suspec GO & 19 Orang $(20,43 \%)$ & 54 orang $(20 \%)$ \\
Herpes Genitalis & 0 & 5 orang $(1,85 \%)$ \\
Kandidiasis & 0 & 16 orang $(5,92 \%)$ \\
Trikomoniasis & 0 & 2 orang $(0,74 \%)$ \\
Lain-lain & 7 orang $(3,7 \%)$ & 46 orang $(8,53 \%)$ \\
\hline
\end{tabular}

Sumber: Profil Dinkes Aceh Tahun 2011

Berdasarkan Profil dari Dinas Kesehatan Provinsi Aceh Tahun 2011 terjadi kenaikan kasus IMS tahun 2012 pada kasus Sifilis 62 orang $(22,96 \%)$, sevisitis sebanyak 44 orang $(16,29 \%)$, suspec GO sebanyak 54 orang (20\%) dan muncul beberapa jenis penyakit IMS lain diantaranya kasus Herpes Genitalis, Kandidiasis dan Trikomoniasis.
Dari data dapat kita lihat pada kenyataannya terjadi peningkatan dari jumlah kasus yang mengalami IMS tersebut.

$$
\text { Upaya pencegahan dan }
$$
penanggulangan IMS/HIV-AIDS di tingkat pelayanan dasar masih ditujukan kepada kelompok berisiko berupa upaya pencegahan dan penanggulangan IMS dengan pendekatan 
sindrom. Saat ini masih ditemui hambatan sosiobudaya yang sering mengakibatkan ketidaktuntasan dalam pengobatannya, sehingga menyebabkan laju epidemi HIV meningkat terutama melalui hubungan seksual. $^{5}$

Pemerintah pada saat ini sudah membuat program penanggulangan penyakit menular seksual termasuk HIV/AIDS di kabupaten/kota, dimana untuk Puskesmas Kuta Alam Banda Aceh hanya beberapa program saja yang sudah dilaksanakan, diantaranya program Komunikasi Informasi dan Edukasi (KIE) sebagai upaya Komunikasi Perubahan Perilaku (KPP) atau Behavior Change Communication (BCC), Program kondom 100\%, Program penanganan IMS, Konseling dan testing sukarela (VCT). Namun promosi tentang kondom belum sepenuhnya mencapai hasil $100 \%$ dikarenakan sosial budaya masyarakat yang masih kurang mendukung upaya tersebut. ${ }^{5}$ Penelitian yang dilakukan yang dilakukan oleh Linda Puspita dengan judul "Analisis Faktor yang berhubungan dengan Infeksi Menular seksual pada Wanita Pekerja seks", didapatkan hasil bahwa penggunaan kondom sangat berhubungan terhadap kejadian penyakit menular seksual $(p=0,002$, $\mathrm{OR}=7,7$ ) sehingga masih sangat perlu adanya sosialisasi tentang mengenai penggunaan kondom dan peningkatan penyuluhan yang harus intens terhadap upaya pencegahan IMS tersebut. $^{5}$ Meningkatnya angka kejadian penyakit Infeksi Menular seksual dikalangan dewasa muda terutama wanita merupakan bukti bahwa wanita dalam hal ini sering menjadi korban dari IMS. Pencegahan merupakan upaya prioritas dalam penanggulangan HIV/AIDS dan IMS. Hal ini berkaitan erat dengan situasi penularan IMS yang ada di masyarakat. Pencegahan penyakit dilakukan melalui upaya kampanye atau penyuluhan tentang seks aman melalui penggunaan kondom yang meliputi pemberian Informasi, Edukasi, dan Komunikasi (KIE) sesuai dengan budaya dan agama setempat sangat diperlukan untuk menghindari penyebaran penyakit.

\section{METODE}

Jenis penelitian yang digunakan adalah observasional dengan metode pengukuran secara cross-sectional. Penelitian ini dilaksanakan di Puskesmas Kuta Alam Banda Aceh tahun 2013.

Populasi adalah seluruh Wanita Usia Subur (WUS) beresiko yang berusia 20-35 tahun yang datang ke Klinik IMS. ${ }^{5}$ Sampel dalam penelitian ini yaitu WUS berisiko sebanyak 63 orang dengan tehnik sampling secara Consecutive sampling dengan menggunakan rumus (Lemeshow et al.,1997) dalam Lemeshow, Stanley, Hosmer, david.W, Klar, Janelle, Lwanga, Stephan.K,1997. ${ }^{6}$

$n \geq \frac{\left(Z_{(1-\alpha / 2)} \sqrt{P_{o}\left(1-P_{o}\right)}+Z_{(1-\beta)} \sqrt{P_{a}\left(1-P_{a}\right)}\right)^{2}}{\left(P_{o}-P_{a}\right)^{2}}$

Pengukuran varibel penelitian didasarkan pada penilaian menurut skala likert untuk mengetahui tingkat kualitas pelayanan yang di harapkan. ${ }^{5}$

\section{HASIL PENELITIAN Pencegahan IMS}

Pencegahan IMS diukur dengan 6 pertanyaan dengan menggunakan skala Likert. Dapat dilihat pada Tabel 1 berikut:

Tabel 1. 


\section{Pencegahan IMS di Wilayah Kerja Puskesmas Kuta Alam Banda Aceh}

\begin{tabular}{lllc}
\hline Item & Jawaban & F & Proporsi \\
\hline Saya membersihkan alat kelamin sebelum & 1. Tidak pernah & 25 & 39,7 \\
dan sesudah melakukan hubungan seks & 2. Kadang-kadang & 15 & 23,8 \\
& 3. Selalu & 23 & 36,5 \\
Saya melakukan hubungan seks hanya & 1. Tidak pernah & 30 & 47,6 \\
dengan alat genetalia & 2. Kadang-kadang & 18 & 28,6 \\
& 3. Selalu & 15 & 23,8 \\
Setiap ada gejala gatal dan perih di daerah & 1. Tidak pernah & 29 & 46,0 \\
vagina saya memeriksakan diri ke klinik & 2. Kadang-kadang & 20 & 31,7 \\
IMS & 3. Selalu & 14 & 22,2 \\
Pada saat sudah mengalami gejala IMS, & 1. Tidak pernah & 34 & 54,0 \\
saya juga mengajak pasangan untuk & 2. Kadang-kadang & 17 & 27,0 \\
memeriksakan diri & 3. Selalu & 12 & 19,0 \\
Saya mengajak pasangan menggunakan & 1. Tidak pernah & 36 & 57,1 \\
kondom dalam berhubungan seksual untuk & 2. Kadang-kadang & 13 & 20,6 \\
terhindar dari IMS & 3. Selalu & 14 & 22,2 \\
Saya hanya minum obat yang diberikan & 1. Tidak pernah & 24 & 38,1 \\
dokter sampai tuntas pengobatan & 2. Kadang-kadang & 19 & 30,2
\end{tabular}

Perhitungan jumlah skor yang didapat menggunakan kategori median untuk menentukan tingkat pencegahan IMS baik dan pencegahan IMS kurang baik. Pada penelitian ini didapat hasil mayoritas pencegahan IMS di wilayah kerja Puskesmas Kuta Alam Banda Aceh adalah pencegahan IMS kurang baik sebanyak 36 orang $(57,1 \%)$. Hal ini dapat dilihat pada Tabel 2 berikut:

Tabel 2.

Pencegahan IMS di Wilayah Kerja Puskesmas Kuta Alam Banda Aceh

\begin{tabular}{lcc}
\hline Pencegahan dan Penanggulangan IMS & Frekuensi & Proporsi \\
\hline Baik & 27 & 42,9 \\
Kurang baik & 36 & 57,1 \\
Jumlah & $\mathbf{6 3}$ & $\mathbf{1 0 0 , 0}$ \\
\hline
\end{tabular}

\section{Promosi Penggunaan Kondom}

Promosi penggunaan kondom diukur dengan menyebarkan kuesioner sebanyak 6 pertanyaan dengan menggunakan skala likert. Dapat dilihat pada Tabel 3 berikut :

Tabel 3.

Promosi Penggunaan Kondom di Wilayah Kerja Puskesmas Kuta Alam Banda Aceh

\begin{tabular}{|c|c|c|c|}
\hline Item & Jawaban & $\mathbf{F}$ & Proporsi \\
\hline \multirow{3}{*}{$\begin{array}{l}\text { Kondom adalah alat pelindung dalam hubungan seks } \\
\text { aman }\end{array}$} & 1. $\quad$ Sangat tidak setuju & 20 & 31,7 \\
\hline & 2. Tidak setuju & 9 & 14,3 \\
\hline & 3. Setuju & 10 & 15,9 \\
\hline \multirow{2}{*}{$\begin{array}{l}\text { Kondom dapat mencegah penularan penyakit infeksi } \\
\text { menular seksual }\end{array}$} & 1. Sangat tidak setuju & 13 & 20,6 \\
\hline & 2. Tidak setuju & 10 & 15,9 \\
\hline \multirow{4}{*}{$\begin{array}{l}\text { Kondom dipakai jika ada gejala penyakit infeksi } \\
\text { menular seksual }\end{array}$} & 1. Sangat tidak setuju & 23 & 36,5 \\
\hline & 2. Tidak setuju & 9 & 14,3 \\
\hline & 3. Setuju & 16 & 25,4 \\
\hline & 4. Sangat setuju & 15 & 23,8 \\
\hline $\begin{array}{l}\text { Penggunaan kondom dapat menyebabkan iritasi tetapi } \\
\text { aman dalam hubungan yang berisiko }\end{array}$ & 1. Sangat tidak setuju & 22 & 34,9 \\
\hline
\end{tabular}




\begin{tabular}{|c|c|c|c|}
\hline \multirow{4}{*}{$\begin{array}{l}\text { Kondom harus dipakai setiap saat pada hubungan seks } \\
\text { aman }\end{array}$} & 3. Setuju & 15 & 23,8 \\
\hline & 4. Sangat setuju & 16 & 25,4 \\
\hline & 1. Sangat tidak setuju & 20 & 31,7 \\
\hline & 2. Tidak setuju & 5 & 7,9 \\
\hline \multirow{6}{*}{$\begin{array}{l}\text { Kondom selalu dipakai walaupun harus dibeli/tanpa } \\
\text { distribusi gratis }\end{array}$} & 3. Setuju & 13 & 20,6 \\
\hline & 4. Sangat setuju & 25 & 39,7 \\
\hline & 1. Sangat tidak setuju & 22 & 34,9 \\
\hline & 2. Tidak setuju & 8 & 12,7 \\
\hline & 3. Setuju & 19 & 30,2 \\
\hline & 4. Sangat setuju & 14 & 22,2 \\
\hline
\end{tabular}

Perhitungan jumlah skor yang didapat menggunakan kategori median untuk menentukan tingkat promosi penggunaan kondom baik dan promosi penggunaan kondom kurang. Pada penelitian ini didapat hasil mayoritas promosi penggunaan kondom pada kategori baik sebanyak 33 orang $(52,4 \%)$. Hal ini dapat dilihat pada Tabel 4 berikut:

Tabel 4.

Promosi Kondom di Wilayah Kerja Puskesmas Kuta Alam Banda Aceh

\begin{tabular}{lcc}
\hline \multicolumn{1}{c}{ Promosi penggunaan kondom } & Frekuensi & Proporsi \\
\hline Promosi baik & 33 & 52,4 \\
Promosi kurang baik & 30 & 47,6 \\
Jumlah & $\mathbf{6 3}$ & $\mathbf{1 0 0 , 0}$ \\
\hline
\end{tabular}

Hubungan Promosi Penggunaan Kondom dengan Pencegahan dan Penanggulangan IMS

Berdasarkan hasil Analisa Bivariat antara hubungan Promosi Penggunaan Kondom dengan Pencegahan dan Penanggulangan IMS pada Wanita Usia Subur (WUS) berisiko diperoleh hasil uji statistic Chi-square nila $p=0,013$ artinya ada hubungan yang signifikan antara Promosi Penggunaan Kondom dengan Pencegahan dan Penanggulangan IMS dengan nilai OR 0,579 dengan Confidence Interval 0,3680,909. Hasil dapat dilihat pada Tabel 5 berikut ini :

Tabel 5.

Hubungan Promosi Penggunaan Kondom dengan Pencegahan IMS

\begin{tabular}{|c|c|c|c|c|c|c|c|}
\hline \multirow{3}{*}{$\begin{array}{c}\text { Promosi Penggunaan } \\
\text { Kondom }\end{array}$} & \multicolumn{4}{|c|}{ Pencegahan IMS } & \multirow{2}{*}{\multicolumn{2}{|c|}{ Total }} & \multirow[t]{3}{*}{$\mathrm{P}$} \\
\hline & \multicolumn{2}{|c|}{ Baik } & \multicolumn{2}{|c|}{ Kurang Baik } & & & \\
\hline & f & $\%$ & f & $\%$ & $\mathbf{F}$ & $\%$ & \\
\hline Baik & 19 & 57,6 & 14 & 42,4 & 33 & 100 & \\
\hline kurang baik & 8 & 26,7 & 22 & 73,3 & 30 & 100 & 0,013 \\
\hline
\end{tabular}

Hubungan Promosi Penggunaan Kondom dengan Pencegahan dan Penanggulangan IMS pada Wanita Usia Subur (WUS) berisiko diperoleh data bahwa dari 33 responden dengan promosi penggunaan kondom baik sebanyak 19 responden $(57,6 \%)$ yang pencegahan dan penanggulangan IMS baik dan 14 responden $(42,4 \%)$ yang pencegahan dan penanggulangan IMS kurang baik. Sedangkan dari 30 responden dengan promosi penggunaan kondom kurang baik sebanyak 8 responden $(26,7 \%)$ yang pencegahan dan penanggulangan IMS baik dan 22 responden $(73,3 \%)$ yang pencegahan dan penanggulangan IMS kurang baik. Hasil uji statistik Chi-square didapat nilai $\mathrm{p}=0,013$ artinya ada hubungan yang signifikan antara 
promosi penggunaan kondom dengan pencegahan dan penanggulangan IMS. Hal ini menunjukkan bahwa pada orang-orang yang berperilaku seksual berisiko tinggi, kemungkinan tertular IMS lebih kecil apabila penggunaan kondom dilakukan secara maksimal dan sebaliknya. Secara medis dan epidemiologis diketahui bahwa kondom efektif mencegah IMS bila digunakan secara benar dan konsisten, kondom mempunyai peranan penting dalam kesehatan masyarakat khususnya dalam pencegahan IMS termasuk HIV dan Hepatitis B. ${ }^{6}$

\section{Hubungan Promosi Seks Aman dengan Pencegahan IMS}

Berdasarkan hasil Analisa Bivariat antara hubungan Promosi Seks Aman dengan pencegahan dan penanggulangan IMS pada Wanita Usia Subur (WUS) beresiko diperoleh nilai $\mathrm{P}=0,029$ artinya ada hubungan yang signifikan antara promosi seks Aman dengan Pencegahan dan Penanggulangan IMS. Nilai OR 0,622 dengan Confidence Interval 0,390-0,992. Seperti pada Tabel 6 berikut ini :

Tabel 6.

Hubungan Promosi Seks Aman dengan Pencegahan IMS

\begin{tabular}{|c|c|c|c|c|c|c|c|}
\hline \multirow{3}{*}{ Promosi Seks Aman } & \multicolumn{4}{|c|}{ Pencegahan IMS } & \multirow{2}{*}{\multicolumn{2}{|c|}{ Total }} & \multirow{3}{*}{$\mathbf{p}$} \\
\hline & \multicolumn{2}{|c|}{ Baik } & \multicolumn{2}{|c|}{ Kurang Baik } & & & \\
\hline & $\mathbf{f}$ & $\%$ & f & $\%$ & $\mathbf{f}$ & $\%$ & \\
\hline Promosi baik & 18 & 56,2 & 14 & 43,8 & 32 & 100 & \\
\hline Promosi kurang baik & 9 & 29,0 & 22 & 71,0 & 31 & 100 & 0,029 \\
\hline
\end{tabular}

Hubungan Promosi Seks Aman dengan Pencegahan dan Penanggulangan IMS pada Wanita Usia Subur (WUS) berisiko diperoleh data bahwa dari 32 responden dengan promosi seks aman baik sebanyak 18 responden $(56,2 \%)$ yang pencegahan dan penanggulangan IMS baik dan 14 responden $(43,8 \%)$ yang pencegahan dan penanggulangan IMS kurang baik. Sedangkan dari 31 (responden dengan promosi seks aman kurang baik sebanyak 9 responden $(29,0 \%)$ yang pencegahan dan penanggulangan IMS baik dan 22 responden (71,0\%) yang pencegahan dan penanggulangan IMS kurang baik. Hasil uji statistik Chi-square didapat nilai $\mathrm{p}=0,029$ artinya ada hubungan yang signifikan antara promosi seks aman dengan pencegahan dan penanggulangan IMS.

\section{PEMBAHASAN}

Pelayanan kesehatan yang dilaksanakan di klinik IMS mencakup: (a) Melaksanakan kegiatan pencegahan seperti promosi kondom dan seks yang aman, (b) Melaksanakan pelayanan yang ditargetkan untuk kelompok beresiko tinggi, (c) Memberikan layanan pemeriksaan dan pengobatan bagi mereka yang telah tertular IMS, (d) Melaksanakan kegiatan penapisan untuk IMS Asintomatic bagi semua populasi yang beresiko secara rutin sedikitnya sekali setiap 3 (tiga) bulan, (e) Memberikan layanan konsling, pemeriksaan, dan pengobatan bagi pasangan tetap klin pekerja seks melalui sistem partner notification, (f) Menjalankan sistem monitoring dan surveilens, (g) Memberikan layanan KIE tentang mitos penggunaan obat-obat bebas untuk mencegah atau mengobati IMS. ${ }^{7}$

Pelayanan klinik Infeksi Menular Seksual yang baik sangat menentukan terhadap baik dan kurangnya upaya pencegahan dan penanggulangan IMS yang ada di Puskesmas Kuta Alam Banda Aceh. 
Bila kita lihat dari hasil penelitian menunjukkan bahwa $57,1 \%$ upaya pencegahan dan penanggulangan infeksi menular seksual kurang baik dibandingkan dengan upaya pencegahan dan penanggulangan IMS baik sebesar 42,9\%. Keadaan ini mencerminkan bahwa pencegahan dan penanggulangan IMS di Puskesmas Kuta Alam masih pada kondisi yang perlu mendapatkan perhatian khusus sehingga masalah IMS menjadi prioritas khususnya dalam peningkatan upaya-upaya yang berkaitan dengan penurunan kasus IMS peningkatan pelayanan KIE, promosi penggunaan kondom, Promosi seks aman yang baik terhadap pencegahan IMS di Puskesmas Kuta Alam Banda Aceh.

Fenomena peningkatan dan penyebaran kasus infeksi menular seksual yang terjadi demikian cepat menyebabkan bahwa penyakit infeksi menular seksual yang sangat berpotensi meningkatkan risiko penularan HIV melalui hubungan seksual sehingga sangat membutuhkan perhatian dalam pencegahan dan penanggulangannya. Upaya tersebut tentunya harus didukung dari tingkat pelayanan yang diberikan secara komprehensif. ${ }^{8}$

Upaya pencegahan infeksi menular seksual kalau dilihat dari promosi penggunaan kondom untuk mencegah IMS pada orang-orang yang berperilaku seksual berisiko apabila penggunaan kondom dilakukan secara maksimal maka kemungkinan untuk tertular IMS lebih kecil. ${ }^{9}$ Penggunaan kondom yang baik akan mengurangi risiko terinfeksi penyakit tersebut, bagi mereka yang tidak mampu berpuasa seks. ${ }^{10}$ Kondom memiliki fungsi double protection yaitu selain untuk mencegah penularan IMS juga dapat digunakan sebagai alat kontrasepsi yang paling efektif untuk mengurangi resiko penularan penyakit seksual. ${ }^{11}$ Orang yang sudah mengetahui dirinya terinfeksi IMS harus tetap menggunakan kondom walaupun sudah divasektomi untuk mencegah penularan IMS terhadap pasangannya, kecuali IMS nya sudah diobati dan sembuh. Meski demikian angka penggunaan kondom pada masyarakat Indonesia masih sangat rendah. Mengingat bahwa tidak ada obat atau inetrvensi dalam pencegahan IMS maka penggunaan kondom secara konsisten dalam berhubungan seksual merupakan cara pencegahan penularan IMS yang paling efektif selain dengan cara abstain seks. ${ }^{8}$

Promosi seks aman yang baik cenderung akan mencegah wanita usia subur untuk terinfeksi IMS. Orang yang memilki IMS dapat berpotensi untuk terinfeksi HIV lebih mudah dari orang yang tidak memiliki IMS. Jika salah satu pasangan memilki IMS maka harus adanya penundaan hubungan hubungan seksual. ${ }^{9}$ Seks yang aman sangat mudah dan efektif untuk mencegah resiko HIV dan AIDS, kehamilan tidak direncanakan serta infeksi menular seksual. ${ }^{10}$

Menurut Raharjo dalam Mardin Purba, 2009 bahwa faktor yang memperlambat upaya mengurangi resiko penyebaran IMS adalah masih kurangnya akses penderita IMS ke sarana pelayanan kesehatan, kurangnya rasa percaya diri, staf klinik yang memilki sikap negatif terhadap kegiatan seks dan penggunaan alat kontrasepsi atau karena ada larangan. ${ }^{11}$

Sesuai dengan pendapat dalam teori proteksi motivasi yang menyatakan bahwa keparahan yang dirasakan akan mempengaruhi keinginan seseorang dalam melakukan suatu tindakan karena tindakan seseorang untuk mencari pengobatan dan pencegahan penyakit didorong oleh ancaman penyakit tersebut. ${ }^{16}$

Hal ini jika dikaitkan dengan data sekunder yang diperoleh di Puskesmas Kuta Alam, ${ }^{17}$ bahwa terjadi peningkatan kasus infeksi menular seksual dari tahun 2011 sebesar 93 kasus menjadi 270 kasus pada tahun 2012. Keadaan ini mencerminkan bahwa sebagian besar upaya pencegahan dan 
penanggulangan IMS belum baik misalnya layanan KIE sebagai upaya komunikasi perubahan perilaku, penapisan terhadap IMS yang berisiko masih menghadapi kendala bahwasanya pasangan mereka tidak membolehkan melakukan pemeriksaan dan pengobatan secara terpadu dan adanya perasaan takut serta malu jika diketahui orang kalau mengalami infeksi menular seksual, terkadang mereka yang mengalami penyakit tersebut akan melakukan pengobatan secara tradisional. ${ }^{18}$

Kondisi demikian disebabkan oleh lingkungan dan kehidupan adat istiadat yang kental serta masyarakat yang akan mengucilkannya dalam berinteraksi secara sosial sehingga pelayanan di klinik IMS belum dapat menjaring para WUS yang berisiko mengalami IMS dalam melaksanakan upaya pencegahan dan penanggulangan IMS. Keadaan ini menunjukkan masih kurangnya minat/ kesadaran masyarakat dalam memperhatikan kondisi kesehatannya.

Sesuai dengan teori Depkes RI, ${ }^{19}$ dijelaskan bahwa kegiatan komunikasi informasi edukasi yang baik akan memberikan penambahan pengetahuan dan perubahan perilaku kelompok sasaran sehingga pesan yang disampaikan akan memberikan perubahan pola pikir bagi kelompok tersebut. ${ }^{19}$ Perubahan perilaku pada kelompok sasaran bukanlah hal yang mudah oleh karena itu harus dilakukan secara terus menerus, berulang-ulang, berkesinambungan sesuai dengan daya serap dan kemampuan kelompok sasaran untuk melaksanakan perilaku yang diharapkan.

Strategi untuk perubahan perilaku berkesinambungan tersebut akan dapat memberikan pemahaman yang baik mengenai unsur-unsur yang berhubungan dengan IMS seperti pengenalan gejala, pentingnya mendapatkan pengobatan segera, pentingnya pengobatan bagi pasangannya sehingga dapat memberikan perubahan bagi upaya pencegahan IMS terhadap masyarakat. $^{20}$

\section{KESIMPULAN DAN SARAN}

Berdasarkan hasil penelitian, analisa Promosi penggunaan kondom didapat hasil uji statistik Chi-square nilai $\mathrm{p}=0,013$ artinya ada hubungan yang signifikan antara promosi penggunaan kondom dengan pencegahan infeksi menular seksual dan hasil uji statistik terhadap seks aman didapat hasil $\mathrm{p}=0,029$ artinya ada hubungan yang signifikan antara promosi seks aman dengan pencegahan infeksi menular seksual.

Kepada Puskesmas untuk lebih mengaktifkan kegiatan KIE (konseling, informasi dan Edukasi) dengan pendekatan pada kelompok beresiko melalui kegiatan penyuluhan, arisan ibu-ibu, pemanfataan kelas ibu hamil sehingga dapat memberikan pemahaman yang dapat meningkatkan kesadaran masyarakat dalam melakukan upaya pencegahan dan penanggulangan IMS.

\section{DAFTAR PUSTAKA}

1. United Nations High Commisioner of Refugee. Buku Pedoman Lapangan Antar-Lembaga Kesehatan Reproduksi dalam situasi darurat. Jakarta. 2010.

2. Ditjen PP \& PL Kemenkes RI. Laporan tentang HIV/AIDS. Yayasan Spiritia. 2013; diakses tanggal 7 April 2013

3. Church World Service (CWS. Pelatih pelatih sebaya untuk HIV/AIDS dan Kesehatan reproduksi bagi siswa SMA di Aceh. ). 2009.

4. Lelyana, L., 'Manajemen Resiko Penularan Penyakit HIV/AIDS di RSUP Dr. Sardjito Yogyakarta'. Tesis. UGM. Yogyakarta. 2006.

5. Komisi Penanggulangan AIDS, Family Health International. Kebijakan dalam penanggulangan IMS, HIV dan AIDS (A-1) . Jakarta. 2009.

6. Laporan Dinas Kesehatan Kota Banda Aceh. 2012.

7. Puspita, L., 'Analisis Faktor Yang Berhubungan dengan Kejadian IMS 
pada Wanita Pekerja Seksual', Jurnal Ilmu Kesehatan 2 (1) 2017, 31-44, dalam

http://ejournal.stikesaisyah.ac.id/index.p hp/eja.

8. Whalley \& Wong's. Tahap perkembangan manusia menurut umur. 1999: dalam www.library.upnvj.ac.id/pdf/2s/keperaw atan/205312044/bab.2.pdf; Akses tanggal 26 Februari 2013

9. Lemeshow, at all, adequacy of Sample Size in Health Studies John Wiley and Sons. 1997

10. Riduwan. Skala Pengukuran Variabelvariabel penelitian. Jawa Barat: penerbit ALFABETA. 2007.

11. Dirjen PP \& PL. Pedoman Layanan konfrehensif IMS \& HIV-AIDS. Jakarta. 2012.

12. Ridha, M., 'Efektifitas Pelayanan Kesehatan di Rumah sakit Umum Kabupaten Polman Sulawesi Barat, Universitas MuhammadiyahMakasar'.Skripsi. 2008.

13. Ditjen PP \& PL Kemenkes RI. Laporan tentang HIV/AIDS. Yayasan Spiriti. 2013; diakses tanggal 7 April 2013.

14. KPA Nasional. Strategi Penanggulangan HIV-AIDS tahun 2007-2010. Jakarta. 2007.

15. Lily, L., 'Hubungan Persepsi Pelayanan Klinik, upaya Pencegahan, Pengobatan Sendiri dan Riwayat IMS dengan Kepatuhan Pemeriksaan Skrining IMS pada WPS (Studi di Resosialisasi Argorejo Semarang tahun 2007)'. Skripsi. 2007.

16. Sumarlan., 'Niat Wanita Pekerja Seks Gajah Kumpul terhadap Pemanfaatan Klinik IMS di Puskesmas Batagan Kabupaten Pati Jawa Tengah. Program Studi Magister Promosi Kesehatan Pasca Sarjana Universitas Dipenogoro, Semarang'. Tesis. 2008.

17. Yulifah, R, Johan, T.A.Y. Asuhan Kebidanan Komunitas, Penerbit Salemba Medika. Jakarta. 2009.

18. Fitriana, N.A., 'Penggunaan Kondom \& Vaginal Hiegiene sebagai factor resiko kejadian infeksi menular seksual pada wanita pekerja seks di lokasi Batu 24
Kab. Bintan', Jurnal Kesmas. 2012; vol. 1 no. 2 tahun 2012.

19. BKKBN, Depkes RI, USAID. Infeksi Menular Seksual (IMS) sebagai masalah kesehatan masyarakat. , 2012; dalam http://archive.k4health.org/toolkist/indo nesia/infeksi menular seksual: Akses tanggal 19 Desember 2012.

20. Mardin, P., 'Pengaruh Karakteristik \& Motivasi Pasien Terhadap Pemanfaatan Pelayanan Klinik IMS di PKM Kabanjahe Karo tahun 2009'. Tesis. 2009.

21. Azmi, N.A., 'Analisis Faktor-faktor Penyebab Niat WPS yang menderita IMS berperilaku Seks Aman(safe sex) dalam melayani pelanggan', Jurnal Promosi Kesehatan Indonesia. 2008; vol.3 no. 2/Agustus 2008

22. Laporan Bulanan infeksi menular seksual (IMS). Puskesmas Kuta Alam Banda Aceh . 2012.

23. Hesti, R.B., 'Persepsi Kelompok resiko tinggi tertular HIV/AIDS tentang Klinik IMS dan Voluntary Counseling \& Testing (VCT) di Puskesmas Padang Bulan Medan tahun 2008'. Akses tanggal 21 februari 2013

24. Depkes RI, USAID \& Family Health International. Standar Operasional Prosedur Klinik IMS. Jakarta. 2007

25. Notoatmodjo, S. Konsep Perilaku Kesehatan. Jakarta. 2002.

26. Depkes, RI, Depsos, BKKBN. Kebijakan Strategi Nasional Kesehatan Reproduksi di Indonesia. Jakarta. 2005. 